\title{
Direct and indirect value creation in offshored knowledge-intensive services
}

Article

Accepted Version

Brandl, K. (2017) Direct and indirect value creation in offshored knowledge-intensive services. International Journal of Physical Distribution \& Logistics Management, 47 (2/3). pp. 137-155. ISSN 0960-0035 doi:

https://doi.org/10.1108/IJPDLM-09-2015-0239 Available at https://centaur.reading.ac.uk/66949/

It is advisable to refer to the publisher's version if you intend to cite from the work. See Guidance on citing.

To link to this article DOI: http://dx.doi.org/10.1108/IJPDLM-09-2015-0239

Publisher: Emerald

All outputs in CentAUR are protected by Intellectual Property Rights law, including copyright law. Copyright and IPR is retained by the creators or other copyright holders. Terms and conditions for use of this material are defined in the End User Agreement.

\section{www.reading.ac.uk/centaur}

\section{CentAUR}

Central Archive at the University of Reading 
Reading's research outputs online 


\title{
DIRECT AND INDIRECT VALUE CREATION IN OFFSHORED KNOWLEDGE- INTENSIVE SERVICES
}

\begin{abstract}
Purpose: Despite increasing interest in offshoring of knowledge-intensive services, it is still undetermined if sourcing of services, truly creates the anticipated value for clients. Moreover, even less is known if there is value created for service providers in the process beyond the general service trade. This lack of knowledge is based on the challenges in capturing value creation, the unique production process of the services and the impact of offshoring on both value creation and the production process. This paper studies offshored service production processes in order to identify direct and indirect value creation for clients as well as service providers in the service production process.
\end{abstract}

Methods: The paper applies a multiple case study method and studies one conglomerate with three offshored service production processes. The chosen method allows investigating the service production process and indirect/direct value creation within the process in detail.

Findings: The study finds that there is direct value creation for the client and the service provider towards the end of the production processes as expected. However, more importantly it finds additional indirect value creation in various production stages. The indirect value is reflected in enhanced understanding of problems and own operations for the client and gained knowledge about clients and problem-solving approaches for the service provider as well as knowledge on international communication and team coordination for both firms.

Research implications: This study contributes to offshoring literature with a comprehensive understanding on value creation in service offshoring for clients as well as service providers. It 
also contributes to service management literature with a study on direct and indirect value creation in services particularly within the production process of the services.

Practical implications: The study allows practitioners to gain insights on the value creation logic of offshored services and the value created beyond that logic. More specific, it allows client firms to gain details of various values and benefits of service offshoring and service provider firms to gain a focused perspective on own value creation in service productions that can lead to competitive advantages.

Originality/value: The paper is novel and original through its approach to study offshoring from a value creation logic perspective including not only the client but also the service provider perspective. It also applies a service production process perspective that is novel in offshoring literature.

Keywords: offshoring, knowledge-intensive services, value creation, service production process

\section{Acknowledgement}

I would like to thank special issue editors Wendy Tate and Lydia Bals as well as three anonymous reviewers for their invaluable feedback and guidance in the review process. I also thank the Otto Mønsteds Fond and the Danish Ministry for Research, Innovation and Higher Education for financial support. 


\section{INTRODUCTION}

Despite the increasing interest in the public and academic sphere on service offshoring, not much is known about the complexities in offshoring (Bals et al., 2013), especially in advanced and knowledge-intensive service offshoring. Issues such as (hidden) costs (Larsen, Manning \& Pedersen, 2014) and loss of control (Ellram et al., 2008; Hartmann et al., 2008) are only two problems caused by these complexities. As a consequence, an increasing amount of offshored services are relocated to and/or reintegrated into the offshoring firm (Bals et al., 2015; Foerstl et al., 2016).

One of the reasons for these reshoring and insourcing activities are the lacking clarity about the kind of value that is or should be created through service offshoring, where in the service production process that value is created and who creates and benefits from this created value. Known is the value creation logic of services, to satisfy needs or solve problems of clients (Normann \& Ramirez, 1994) or the general benefits of offshoring, such as cost reduction or access to skilled labour (Manning et al., 2008).

The shortage of research is largely due to three challenges; a) general issues in depicting value creation in service productions (Andersen \& Narus, 1998; Macdonald et al., 2011; Payne et al., 2008), b) the focus of academic literature to predominantly study offshoring in a static manner not acknowledging the dynamics of service processes (for exceptions see Kedia \& Lahiri, 2007, Tate et al., 2009 and Jensen, 2012) and c) that offshoring is primarily studied from the client perspective, providing only a restricted and biased picture of activities. However, services are co-produced by clients and service providers (Mills et al., 1983; O’Farrell \& Moffat, 1991) and are dynamic (Prahalad \& Ramaswamy, 2000; Grönroos, 2012) requiring a process view on the production of the services including client and service provider activities. 
This paper aims to contribute to the outlined research gap through a study of the value creation in service production processes of offshored knowledge-intensive services. Put differently, the paper studies the created value for clients and service providers in a production process of offshored knowledge-intensive services.

Trough a multiple in depth case study that depicts three offshored service production processes, this paper studies activities of actors and the created value in service offshoring. As a result, directly and indirectly created value that benefits the client and service provider is found. Direct value is exchanged between the client and service provider as part of the offshoring contract, such as service deliveries and financial reimbursements. Indirect value is value that is also gained through offshoring, but is not considered to be explicitly part of the service trade, such as organizational learning or enhanced knowledge on international operations.

Value creation for the client in an offshored service context is still directly created value through the value creation logic of the services and the reduced costs that is evident in offshoring to emerging markets. However, clients gain indirect value through an enhanced understanding of problems and operations as well as enhanced international communication and team coordination experience. Similarly, service providers do not only benefit from direct value such as financial reimbursement but also indirect value such as knowledge on the client, the problem that needs to be solved, and the perceived service quality as well as enhanced international communication and team coordination experience. In sum, client and service provider gain international communication and team coordination skills through service offshoring and while the client benefitted from enhanced knowledge and understandings of own operations, the service provider was able to gain significant knowledge resulting in competitive advantages.

The paper is structured as follows. First, a theoretical framework is provided that explains and elaborates on literature of value creation and the production process of knowledge-intensive services with regards to offshoring. After explaining the chosen research approach in the 
method section, data is analysed in line with the production process of the chosen services. Last, a discussion and conclusion is provided, including a discussion on theoretical and practical implications and limitations.

\section{FRAMWORK}

\section{Value creation}

Services are considered to be the application of competences by one party for the benefit of another (Vargo et al., 2008). Competencies are predominantly implied in actions of individuals that own them. However, these activities are not based on linear and regular production processes with inputs, transformation processes and outputs. Services are characterized to be intangible, heteregenous, inseparable from their source of origin, and perishable (Zeithaml et al., 1985), characteristics that challenge production processes. Thus, in a service context, especially with regards to knowledge-intensive services, value creation is not easily accessible. In its most basic sense, value creation is reflected in some form of change such as cost reductions, increased speed of the production of services, increased quality or improved reliability on services (Normann \& Ramirez, 1994).

Generally, value is considered to be the outcome of benefits minus sacrifices (e.g. the trade-off between a focus on core competences and other activities) (Ravald \& Grönroos, 1996) and is a subjective and individual concept. The concept often varies in a cultural, organizational, and relationship context (Ravald \& Grönroos, 1996; Weerakkody \& Irani, 2010). Moreover, researchers emphasise monetary terms of value (e.g. Anderson \& Narus, 1999) or focus on nonmonetary benefits and sacrifices, such as competitive gains, competencies, social relationships, knowledge, and managerial time spent (Flint et al., 1997; Ravald \& Grönroos, 1996). If value is considered to be monetary or non-monetary is often also considered in line with the 
discussion if value is purposefully/instrumentally created or emerges also non-purposefully. In this paper, value is considered to be monetary and/or non-monetary and emerges purposefully and non-purposefully (see a more thorough discussion on creation/emergence of value below).

In a service context, activities require the co-creation of value by actors, such as firms, employees, customers, stockholders, governmental agencies and other entities, through interaction, keeping in mind the beneficiary of the service outcome, the customer (Normann \& Ramirez, 1994; Vargo et al., 2008). Particularly the co-creation of value by client and service provider is emphasised in academic literature (Grönroos, 2012; Prahalad \& Ramaswamy, 2000; 2004). This value co-creation leads to the creation of value-in-use (Vargo \& Lusch, 2004; Vargo et al., 2008), which is important for the service production in itself and emphasises the value that is created as a service delivery.

This value-in-use is equal to the service offering for the client and reflects the value creation logic of services to create value for a client by satisfying a client's need or solving a client's problem (Normann \& Ramirez, 1998). Nonetheless, the process to create this value might also have implications for the service provider and generate additional value to other actors that are part of the production process (Grönroos, 2012). Specifically, while the client is provided with a service output that creates value directly in return for reimbursements for the service provider, the service provider and client might gain indirectly value in the production process (Walter $e t$ $a l ., 2001)$. This indirect value is not part of the general service trade between the client and the service provider and does not belong to the main value creation logic of services (Normann \& Ramirez, 1998). It can be considered as complementary value that is not created purposefully and often might be hidden, but is still generating value that is beneficial to actors in the production process. Grönroos (2012) considers this value as actionable information and splits it into direct and indirect levels. 
Considering the argument of direct and indirect value creation when studying offshored service productions, a more detailed aspect of value creation is possible and is argued to provide insights in the value creation possibilities of offshored knowledge-intensive services. This paper will capitalize on the distinction of direct and indirect value creation to provide these insights. While directly created value is often openly traded value, which is the basis for a service trade and is predominantly the exchange of knowledge for monetary equivalents, indirect value is not openly traded and considered to be a consequence of direct value creation.

\section{Value creation in service production processes}

Etymologically value creation infers simultaneous value consumption, meaning that the creation of value implies also that the value is recognized and consumed and that value creation is a dynamic activity. Not only the created value is of importance but also how the value is used (Vargo \& Lusch, 2004; Woodruff, 1997) and integrated to benefit the firm. A static perspective on value creation is thus not feasible, requesting dynamic approaches for example through a process perspective.

Moreover, in order to understand the creation of value in a service context, the characteristics of the services need to be understood. Services are considered to be the trade of resources and knowledge, especially in the context of knowledge-intensive services. Bettencourt, Ostrom, Brown and Roundtree (2002: 101) define knowledge-intensive services as "accumulation, creation or dissemination of knowledge for the purpose of developing a customized service [...] to satisfy the client's needs". The services request a service production by educated employees who are linked to research and scientific knowledge developments within their areas of expertise. Moreover, the services are based on professional assessments as well as personal judgments by experts (Løwendahl, 1997; Løwendahl et al., 2001) and customization as well as 
participation of clients (Grönroos, 2012; Maister, 1993). The services are often based on research as well as analysis activities in financial (i.e. equity research), pharmaceutical (i.e. clinical trials, drug discovery), legal (i.e. intellectual property research), analytical (i.e. data research/integration/mining) as well as R\&D (i.e. product design, innovation) related activities of a firm (von Nordenflycht, 2010).

Based on the discussed characteristics of services and the issue with the concept of value creation in relation to services, commonly used models to depict value such as Porter's (1985) Value Chain do not efficiently explain value creation in a service firm (Armistead \& Clark, 1993; Løwendahl, 1997; Stabell \& Fjeldstad, 1998; Sutton \& Staw, 1995). Particularly the sequential and project-based nature of the services challenges the applicability of these frameworks. As a consequence, Normann and Ramirez (1998) argue for value constellations that consider value to be co-created by actors that interfere and interact with each other for the service context. In line and based on Normann and Ramirez (1998), Stabell and Fjeldstad (1998) argue for an inclusion of the service production process when studying value creation in knowledge-intensive services. As a consequence, the authors developed the Value Shop model comprising of a service production process.

The framework includes five stages (problem-finding \& acquisition, problem-solving, choice, execution, monitoring \& evaluation) that reflect the production process of knowledge-intensive services. In the problem-finding \& acquisition stage the problem is recorded, reviewed, and formulated. The problem-solving stage associates with the generation and evaluation of alternative problem solving solutions. In the choice stage a problem solving approach is chosen before the approach is communicated, organized, and implemented in the execution stage resulting also in a service delivery. The monitoring \& evaluation stage is measuring and evaluating to what extent the implementation solved the initial problem statement. This service production process with its five stages is very similar to various other service production models 
in service (operations) management literature (see for example Aarikka-Stenroos \& Jaakkola, 2012) and has been used in several industry contexts (see for example Maister 1993 in the IT services industry). The paper follows the framework to identify the different production process stages in order to identify where, when, how and what type of value is created in the production of offshored knowledge-intensive services.

\section{Value Creation in offshoring}

In a knowledge-intensive service context value is created through cost reduction/increased revenues or usable, reliable, and qualitative service deliveries. This value creation logic is somewhat similar to the general objectives of service offshoring. Various researchers (e.g. Manning et al., 2008; Ellram et al., 2008) argue that offshoring value is created through monetary benefits, but also the access and availability of knowledge and knowledgeable experts or further non-monetary value such as competitive gains, competencies, and social relationships (Flint et al., 1997; Ravald \& Grönroos, 1996).

However, the aspect of usable, reliable and qualitative services has been challenged in service offshoring. Many cases exist where services were reshored and reintegrated into the clients operations, as service quality was not secured, or sourced from close locations in order to control usability, reliability and quality in a more efficient way. Major challenges are the disconnection between the service provider and the client through geographic distance. This disconnection is challenging for a service that is based on co-production and knowledge (tacit and explicit in nature) such as evident in knowledge-intensive services, as the created distance impacts the transfer of knowledge and the interaction between the two parties.

International business and offshoring literature have studied different types of distances that impact these activities such as cognitive distance (Bertrand \& Mol, 2013), cultural distance 
(Peeters et al., 2014) or institutional distance (Gooris \& Peeters, 2014). These different distances influence the production of the services and value creation. However, of interest in this research are chains of activities and the impact of offshoring on these activities, as also evidenced by Apte and Mason (1995) and Li and colleagues (2008).

When combining the above theoretical discussion, a theoretical framework as in Figure 1 can be created. It allows visualizing the co-production of the services and the created value for the client as well as the service provider in the production process of the services.

Insert Figure 1 about here

\section{METHODS}

The study aims to elaborate and then extend existing theory (Ketokivi \& Choi, 2014; Stuart et al., 2002) by using a process perspective on service offshoring. In order to do so, it applies a multiple case study approach (Eisenhardt, 1998). It studies one conglomerate with various business unites whereof three are part of this study. The multiple case study approach allows for in depth and detailed analyses of value creation in the production process of knowledgeintensive services.

The chosen cases belong to a Danish conglomerate with two business units that are located in Europe, which are considered to be clients, and one business unit, aka the service provider, located in India. Three services are offshored from these two business units, which are headquartered in Europe. The business units offshore to a global service centre (GSC) in Pune, India. Each firm has own financial interests within the conglomerate structure and their 
offshored services are allocated to own teams established in the GSC. The services under study are Market Intelligence (Case A), Project Management Support (Case B) and Financial Management Reporting \& Reconciliation (Case C) (see Table 1 for further information on the services).

The unit of analysis in this study is the value creation in the production of knowledge-intensive services. Through the service production in this collaboration, value is created for the client and service provider. In order to study this value creation and the resulting benefits of service offshoring, it is important to take the client as well as the service provider perspective into account. Moreover, the research combines an activity level, the production process of the services, with a firm level outcome; the created value for both firms the client and the service provider. Hence, a combination of both levels, the activity level and the firm level, will allow detailed insights on the value creation for clients and service providers in the production process of knowledge-intensive services.

Insert Table 1 around here

\section{Data sources}

Data was generated through an analysis of primary and secondary data. Primary data was generated through 51 semi-structured interviews with individuals that are involved in the production process of the services or in the management thereof. 33 of these interviews were with representatives of the GSC while 18 interviews were conducted with representatives of client firms. Each interview lasted on average 42 minutes ranging from 30 minutes to one hour and 13 minutes and were conducted between June 2012 and January 2013. If information was 
missing follow-up or clarification interviews were conducted, until saturation of information was reached. Each interview was recorded and transcribed. Questions were asked on offshored service production processes and created value for firms.

Data was retrospectively generated and allowed gaining a good understanding of the production process as well as the value created for both firms, clients but also service providers. This retrospective data generation also allows analysing relationships between the cause of actions and their effect on value creation (Van de Ven, 2007; Voss et al., 2002). To avoid problems with memory loss of interviewees and issues with retrospective sense making biases (Voss et al., 2002) some secondary sources were used that mainly provided insights on the production process such as standard operating procedures (SOPs), enabling triangulation (Yin, 2003). Due to the sensitivity of the services, firms tend to document activities, which provided rich secondary data with detailed timeframes. As the research focuses strongly on experts with high dependencies on individual perspectives, it was important to gain multi-level data in order to reduce bias from the interviewees. However, these documents predominantly showed the production processes, not the created value. To identify value creation, more specific questions on the benefits of the services and benefits of the service production processes were asked (see a more elaborate discussion on the data interpretation in the section research process). Table 2 summarizes how issues with validity and reliability of data were addressed.

Insert Table 2 about here

\section{Research process}


A narrative cross-case analysis is used in order to analyse the value creation in the offshored service production process. It is argued that the cross-case analysis allows studying all four cases at the same time taking the same perspective and interpretation approach. The data analysis starts with an outline of offshored service production processes, in order to allow an identification of value creation of the services. This stage of the analysis applies a temporal bracketing strategy (Langley, 1999) and allocates the activities observed in service production processes into different production stages. Stabell and Fjeldstads (1998) Value Shop model is used to distinguish between production process stages in accordance with the models stages of problem-finding \& acquisition, problem-solving, choice, execution and monitoring \& evaluation. The aim of the section is to provide a better understanding of the services and their service production processes before discussing the resulting value creation within the processes. It allows distinguishing between activities of the client and services provider, which then allows to identify when the client is also co-creating value. Moreover, it supports the argument that all three services can be classified as knowledge-intensive services in line with Stabell and Fjeldstad (1998) and von Nordenflycht (2008).

After this analysis, direct and indirect value creation in the production of the services is analysed. The value created for the service provider and client are separately discussed and analysed. It was important to distinguish between value creations of both actors in order to understand the created value in the production process of the services. Moreover, the value is distinguished into indirect and direct created value. The identification of direct value creation is based on the service trade and the contract between the client and service provider. This type of value is negotiated before the service is produced and is argued to be a trade between the service provider and client. Both parties needed to identify if direct value was fully created and if this direct value would not have been created, offshoring would be considered unsatisfactory and activities would likely be reshored. Instead of using the uncertain term value creation, often 
the term had to be further explained and substituted with the term benefits. Moreover, how much or little value was created was not considered to be focus of the study. More important was the aspect that value was created. The distinction on the amount of value is challenging and dependent on subjective interpretation of value. For the purpose of the study, the mere fact that value was created and in what form was sufficient (see a more thorough discussion on limitations of the study that additionally discussed the issues related to the concept of value in the conclusion section of the paper). Direct value was monetary (e.g. financial reimbursement for the service provider from the client) and non-monetary (e.g. the service deliverable from the service provider to the client).

Indirect value is considered to be value that is not directly related to the service trade but a result thereof and outside of the service contract. It is considered to be complementary value as a result of the production of the services. Specific questions were asked according to the value of the services aside from regular trade benefits of the services. Moreover, activities in the production process by client and service provider employees where identified and questions related to associated value were asked. If the value was integrated into the firm and transferred into capabilities was not focus of the study. This integration of value, especially of indirect value, is often based on absorptive capacities of firms (Cohen \& Levinthal, 1990).

\section{DATA ANALYSIS}

Before discussing direct and indirect value creation in the production process of knowledgeintensive services, production processes of services are outlined. Table 3 provides an overview of production processes of all three cases. It shows that service providers and clients are both part of the production process and demonstrates that value is co-created in various stages. The client and service provider play both important roles in this production and execute various activities in the process. In most stages, the client and service provider execute activities related 
to the production process together. In the first two stages, the client implies an important role in establishing the pre-requirements for the following three stages. Without the active participation of the client in the first stages, the following stages are more challenging, as the service provider could potentially suffer from a lack of knowledge. The service provider is more active in middle and end stages, where the service is executed and delivered. In all cases it becomes clear that the client and service provider co-produce the service and thus value is also co-created by both parties. The following sections will elaborate on this value creation with a focus on direct and indirect value that is created in the production process of the services.

Insert Table 3 about here

\section{Direct value creation}

Client. Direct value is predominantly created in the execution stage when the service is delivered from service providers to clients. The service delivery is codified and documented when transferred to the client. This delivery implies a solution to the clients problem and creates value to the client. If the service delivery is not satisfactory, the service is resend to the service provider and amended till a level is reached which is satisfactory for the client. As the service is produced in a long-term arrangement, both parties are keen on finding the right solution for the service delivery in the execution stage. It is emphasised in all cases, that at this stage, the client and service provider are working together to make the delivery as beneficial as possible for the client. Especially in Case B, where the service delivery is of a project based nature the service provider and client constantly amend the service till the project is over and a beneficial outcome is reached for the client. In line, an Analyst of CB recalls: "I'll share the draft with 
everyone, ask for the inputs, change if required, or ask for feedback and then roll it over once it is finalized."

In all cases, it is argued that there is a cost reduction in using an offshore service provider for the production of the services and value is created through reduced costs. The cost aspect is particularly emphasised in Case A and C; "the main driver is cost, at least in the beginning, and then we want to see some of these other facts twiggling in" (Head of Offshoring, CC).

The services require a deliverable that is easy to adopt for example in form of reports, information and deals with various short-term requests. Case B on the other hand is more often dealing with long-term requests on continuing and permanent basis. The service production is dependent on the length of the project and the execution of the project is often lasting over various months. Especially the aspect of trust generated through long-term relationships is argued to enhance the cost reduction as no additional search costs or new establishment costs are encountered.

Service provider. Direct value is created for the client especially in the execution stage, when the service provider pays the client after service delivery. This type of value is monetary in nature. In all cases the most critical and essential value created for the service provider is the monetary reimbursement of the service delivery. This monetary reimbursement and the service delivery are the basis of the service trade and the value creation logic of the services to satisfy a clients needs.

\section{Indirect value creation}

Client. In the first stages of the service production process, the client is required to formulate service requirements and identify problems. This formulation of problems requires the client to understand own processes and to effectively formulate and communicate problems to an 
external provider with often a diverse set of expertise. The effective formulation and communication of problems is necessary to allow a consecutive beneficial execution of the service production process as each earlier production stage influences consecutive stages. Managers are aware of the responsibility to identify the right problem and communicate this problem in an efficient manner as the Offshoring Director, CA outlines: "we create a lot of SOPs, work instructions, engagement frameworks, communications and things like that. It does become very documented so people know what they need to do and what they need to deliver [...]." Similarly the counterpart in the GSC elaborates with "we write SOPs together and have everything approved. So we both know this is how we work this is the output this is what you can expect from deliverables". This problem-finding approach allows clients to step back and reflect upon own systems, approaches and models. Especially in Case B with often very diverse projects, the problem identification stage is central for the further production process. The services are more uncertain then the services of Case $\mathrm{A}$ and $\mathrm{C}$ and requires more often a reevaluation of the initial problem.

Moreover, clients with predominant backgrounds from Europe are able to gain experience in the communication with Indian employees. Experts have most of the time teams on-site and are not required to communicate with staff abroad; "I think again you know for some people who work in a group who have been out, they do have a different mentality than the people who are just sort of been in one country. I think that they are more open [...] So I think there is a lot of things you benefits with global teams" (Offshoring Director, CB). Only in Case B the team has significant experience with international productions. This aspect is not solely related to the different international backgrounds, but also the differences in expertise levels of individuals that are evident. While the client is dealing with operations on a day-to-day basis implying a vast amount of knowledge from individuals on the operations, the service provider only deals with a specific part of operations getting only a restricted view on the overall activities. 
However, in many cases a broader knowledge base allows for a better understanding of activities and issues. Also service providers are predominantly dealing with issues clients have within a particular activity, gaining only knowledge when an issue occurs or problem needs to be solved, restricting and influencing the perspective of client operations.

In line, the managers of the team are coordinating teams that are located across country borders securing that the on-site and offshore team works together. This geographic spread requires the mangers to enable and support the communication between the two parties. The communication is outlined to be a central point especially in the problem-finding, problem-solving and execution stage in all three cases; the Onshore Team Manager from Case B explained "I think it's always tricky to manage remotely. So you have to set it up the way you are most comfortable and at least for myself it is phone calls. We set up at least a regular phone call once a week, they have an opportunity to go through issues or things we need to discuss and I will bring up some points. And by now we are also very comfortable. They have a certain attitude to work and when they have questions and concerns or they will need some guidance they usually get on the instant communicator and just say I have a question and then we will deal with it". Regular phone calls and instant messages on a daily basis are major communication tools. The intention is integrating the offshore team as much as possible in onshore operations.

Based on work related and background differences, the clients also gain insights in efficiency improvements during production processes. Indian service provider emphasizes lean production processes with a heavy focus on efficiency improvement methods such as six sigma process improvements; "we try to understand what their process is and we try to see the low hanging fruits in their processes, low hanging fruits are the problems that can be fixed immediately. If it is designed properly, we classify certain processes according to a family of processes and then apply Lean Six Sigma tools to improve the processes" (Global Business Process Improvement Manager, GSC). This knowledge is especially apparent in the problem- 
solving stage and to some extend in the execution stage of all cases. With the additional process improvement expertise, the client is able to gain an enhanced understanding of own operational efficiency.

Service provider. In the early stages of the production process especially in the problem-finding $\&$ acquisition and the problem-solving stage, the service provider and the client work closely together to make sure that all participating actors understand the service requirements and the possible as well as anticipated service delivery. In this stage, the service provider is interactively trying to find out as much as possible about the clients problems/needs. The gained information creates an indirect value to the service provider as more and more insights on the client are gained. This information is used by the service provider to offer additional services to the client, which are coined to the client's unique characteristics. Moreover, this knowledge is collected and stored in firm internal knowledge platforms that enable sharing of best practices. Especially with regards to strategically important services such as market intelligence, knowledge sharing with all employees can help in decision-making processes.

In the problem-solving stage the service provider learns and or develops a strategy to solve the clients problem/need. In some cases such as in Case $\mathrm{C}$ the client is less participatory than in the problem-finding \& acquisition stage but remains a part of the production phase. In other cases such as in Case B, the client remains heavily involved in the stage and continues to co-produce the service; "In the business owners we have a number of calls on how they look at the figures for the next year. What are the new projects or what are the new changes. We have a lot of calls and communication with them" (Analyst, CB). Thus, the stage allows creating value to both firms the client and service provider as through the exchange of ideas, new possible solution methods can be found and implemented. This stage provides the service provider with the possibility to create indirect value related to possible problem-solving strategies. All 
approaches are, similar to the arguments above, documented and stored in the service providers' knowledge sharing databases. Due to the fact that all services are offshored from business unites of one conglomerate to the GSC, this information is freely shared within the firm, creating indirect value to the service provider. Team members of the GSC were incentivised to use this knowledge-sharing platform to share best practices.

In the execution stage and similar to the client related value creation, the service provider and client continue to communicate. The created value is thus, in line with the created value for the client. Differences between the created values for the two parties in this stage relate to the value creation logic of services, to solve a client's problem/satisfy a client's needs. While the intention of enhanced communication for the client is to support the execution of the services, the service provider's task is to provide the service through executing the tasks. There are clear differences in intentions and activities in this task based on the value creation logic. Nonetheless, there is also an element of enhanced communication between the two parties based on the execution of the service in this stage. The service provider gains communication skills and creates value due to these skills similar to the created value for the client.

Once the service is delivered to the client, the service provider prompted to get feedback from the client in the monitoring \& evaluation stage. The feedback was part of the service production process and allowed the service provider to gain insights on quality of the services for further service improvements. This information is in all three cases not only used for the specific service centre for the respective client but was also integrated to enhance service deliveries and quality in production processes for a variety of different services.

\section{DISCUSSION}

The paper aims to outline value creation for clients and service providers in a production process of knowledge-intensive services. In distinguishing the different production stages and activities 
within the stages, it is possible to analyse where value in the production process is created, what kind of value is created, who creates the value and for whom it is created. The production process and the value creation is thereby reflecting Aarikka-Stenroos and Jaakkola's (2012) client and service provider roles in production processes. Table 4 summarizes the findings and provides an overview of the created direct and indirect value in the production process of the services.

Insert Table 4 about here

The overall value creation logic of services is to satisfy a client's needs (Norman \& Ramirez, 1998). However, despite the direct value, which goes in line with this value creation logic, additional indirect value is created that supplements the overall value creation logic of services. The data shows that direct value is mainly created in the execution stage and benefits the client as well as the service provider. The service delivery that solves a problem or shortcoming for the client reflected in reports and model enhancements in Cases A and B and in form of project support in Case $\mathrm{C}$ is traded for monetary value in form of financial reimbursements. These service trades in line with the value creation logic of services, reflect the purpose and definition of knowledge-intensive services (Bettencourt et al., 2002). Once the client uses this created value and capitalises on the gained knowledge, its problem can be solved or need satisfied. However, this value-in-use is dependent on the absorptive capacity (Cohen \& Levinthal, 1990) of the client to integrate the service delivery into the organization and share the gained knowledge. If and how the client uses the created value goes beyond the scope of this paper. 
An additional direct value creation for the client is the cost efficiency that is evident for the client instead of producing the service internally in a non-offshoring context supporting findings by various offshoring researchers (e.g. Ellram et al., 2008; Murray \& Kotabe, 1999). The clients argue thereby not solely for a cost reduction through lower wages of the individual experts that produce the service but also emphasise the overall long-term set-ups. This argument of enhanced trust and benefits for value creation through long term relationships relates to academic literature on alliances (e.g. Kale et al., 2002).

Despite direct value creation, indirect value is additionally created. This indirect value is not part of the service creation logic to satisfy a client's needs/solve a client's problem and is not accounted for in the service delivery. It is created as a consequence of the production. Both parties the client and the service provider have additional indirect value creation in various stages of the production process. For example in the problem-finding and acquisition as well as in the problem-solving stage, value for the service provider is indirectly created through knowledge and information that is shared within service providers and benefits the organization as a whole. This information provides insights on best practices to solve problems or additional information about the client with the potential to offer additional services to the client. Moreover, the service provider is able to gain knowledge on the quality of the services as perceived by the client, which creates value with regards to service offerings. The service provider is able to incorporate this knowledge to generate better and more efficient problem solving approaches as well as more qualitative services. Thus, despite the financial reimbursement, the service provider gains indirectly value that helps to offer more advanced and better services. These insights can potentially improve the competitive advantages of the firm.

Indirectly created value is often not recognized in service offshoring literature, especially considering service offshoring to emerging market economies such as India. However, 
especially for these firms, which are often lacking behind firms from mature market economies (Brandl et al., 2015; Awate et al., 2012), understanding and acknowledging the indirectly created value and appropriating this value to offerings and service production processes can provide great possibilities.

The value for clients is related to differing backgrounds, i.e. related to cultural or cognitive distance $^{1}$ (Bertrand \& Mol, 2013; Nooteboom, 2009) between onshore and offshore representatives. Clients are required to evaluate problems and operations in the fist two stages of the production process. This evaluation enhances the understanding of the problems and operations of the client firm. The service provider additionally enhances this understanding with a new perspective on activities and different experiences from a firm external perspective. Only a different background and a cognitive distance between onshore and offshore representatives, including the operations efficiency approached driven by the Indian service provider, creates value.

In sum, there are various interesting points to consider with regards to indirect value creation. While clients generally gain an enhanced understanding of own operations also with regards to communication as well as coordination of individuals and teams in an international business context, the service provider gains new knowledge about the client and possibilities of new service offerings. The enhanced understanding for the client is based on the fact that the on-site experts have to reflect upon own activities and operations, which are only possible through offshoring. Moreover, the enhanced distance, be it cultural, cognitive or in terms of activity related expertise, value is created to the client that goes beyond the value creation logic of services. The created value for the service providers is predominantly in relation to knowledge gained about the client, its operations and co-created problem-solving approaches. Also based

\footnotetext{
${ }^{1}$ Nooteboom (2009: 66-67) interprets cognitive distance as "people will perceive, interpret and understand and evaluate the world differently to the extent that they have constructed their cognition along different, weakly connected life paths"
} 
on cultural, cognitive and educational differences, this created value enhances the service provider and allows creating competitive advantages for the firm.

Moreover, some of these values, direct and indirect, are based on the general value creation logics of services and others are more related to the offshoring context. For example, the fact that the service provider gains direct value through a more cost efficient service production is part of the value that offshoring, especially to emerging and low cost countries, allows. Or the indirect value for the client of enhanced understanding of operations that bring a more efficiency enhanced context from the offshoring location in India. These aspects are based on the international and cross border activities of service offshoring. Other aspects are more related to the general characteristics of services such as the delivery of services in exchange for financial reimbursements or the collaboration between a client and a service provider that includes and enhances communication between the two parties. However, this enhanced communication is influenced by cross border communication and issues in relation to country differences and individual or organizational cross border communication (Bhagat et al., 2002; Simonin, 2004).

Despite the findings of indirectly created value in the production of services, of major importance to the offshoring activities is still the directly created value. If there is no beneficial direct value creation, even a vast amount of indirectly created value does not lead to a valuable offshoring set up and could lead to reshoring (Foerstl et al., 2016).

\section{Implications for theory and practice}

This research has various implications for theory and practice. First, the research adds to existing offshoring and international business literature with a detailed and process-oriented study on value creation in service offshoring. The chosen process-orientation is novel in the 
field of offshoring and service offshoring in particular (see also Jensen, 2012). Previous research has predominantly studied offshoring in a static manner, studying a point in time before offshoring activities are initiated or the outcomes and benefits of offshoring. Thus, the study allows gaining a deep understanding of the activities in service offshoring, which is much more detailed to previous research and adds to existing service offshoring literature with new insights and detailed explanations on the activities.

More specific, this research shows that the characteristics of services and in line the production process of services are important and impact outcomes and the value of services (see also Apte \& Mason, 1995). Neglecting the production process of the services cannot provide a comprehensive understanding of service offshoring. In applying Stabell and Fjedstadt's (1998) value shop framework the needed perspective is gained that allowed dissecting the production process into production stages and studying service offshoring in a process manner. Particularly noteworthy is the insight on the value that is created in the service production stages and who creates this value.

Studying the different value possibilities such as directly and indirectly created value allows providing more information on the benefits or challenges of service offshoring. Walter, Ritter and Gemünden (2001) argue that the service provider and the indirectly created value for the service provider are often neglected in service management literature and service design literature. Thus, although this paper started to shed light on direct and indirect value creation for clients as well as for service providers, more research is needed.

Moreover, while there are studies that discuss the benefits of offshoring for client firms, the service provider perspective is often neglected (Jensen, 2012; Kedia \& Lahiri, 2011). Thus, taking the service provider as well as the client into account when studying value creation in service offshoring, allows providing a more extensive perspective on the activities. 
Despite the implications for theory, this research has various implications for practice. Practitioners can use resulting findings as the foundation to identify if service offshoring is beneficial or if services should be reshored or insourced. Gaining information on the direct and indirect value through offshoring allows for much more detailed information beyond the general service trade. Especially information of indirectly created value for the client is novel and allows firms to evaluate or re-evaluate activities. Thus, choices of service providers, the length of relationships or the location of providers are influenced by this knowledge. Even switching the provider occasionally to enhance indirectly created value could be a possibility based on the gained knowledge of indirectly created value for the client.

In line, considering the location of the provider, i.e. near- or farshoring, has the potential to influence service provider choices, as there is the prospect that differences benefit indirect value creation. Thus, detailed knowledge on service offshoring that practitioners can gain from this study allows for new considerations as well as possibilities with regards to offshoring activities of services. These considerations go beyond the general value creation logic and service trade.

Moreover, service providers can benefit from detailed knowledge on the created value in offshoring activities beyond the service trade. It allows identifying indirect value created through collaboration with clients. Consequently, firms are able to capture this value more consciously and use it for own benefits. Moreover, the applied process perspective provides details on production process stages, in which stage indirect value is created and who creates or influences this creation. The detailed perspective allows practitioners to recognize the indirect value creation easier. For internal value considerations and service offerings, this information is important and could result in competitive advantages for the firms also enhancing their catch-up process (Awate et al., 2014). 


\section{CONCLUSION}

The paper set out to study the value creation possibilities in an offshored production process of knowledge-intensive services. It emphasises direct and indirect value creation for clients and service provider. The paper finds that direct value creation is benefitting the client and the service provider towards the end of the production process in line with the expected value creation logic of services and service trade. More importantly, it also finds that indirect value creation significantly benefits the client and service provider within this production process. Clients benefit from created value in relation to an enhanced understanding on own problems and operations as well as from a better international team coordination and communication. Service provider benefit from created value in relation to knowledge about the client and problem-solving strategies as well as a better understanding of perceived quality of the offered services as well as international communication and team coordination as well. In conclusion, even a vast amount of indirectly created value does not substitute the value created through directly created value, but it allows for higher benefits in service offshoring. If direct value is not created, even vast indirectly created value will not prevent a failed service offshoring, which could result in reshoring of activities.

Despite thorough research, the paper has various limitations. First, there are various limitations with regards to the chosen research method. A holistic and dynamic perspective on the phenomena under study was chosen that does not aim for generalization of findings but rather on concepts. The study provides a detailed depiction of production processes of knowledgeintensive services including the value creation within the process. Due to the special characteristics of knowledge-intensive services and the wide variety of services with different levels of knowledge-intensity, generalization within this context is generally challenging to achieve as researchers have noted (e.g. von Nordenflycht, 2010). However, this opens up more 
possibilities for future research that could study the production process of diverse services in more detail.

Moreover, future research should continue taking a production process perspective, which also allows for example to identify reshoring influenced changes in production processes. Such a perspective goes beyond cost or resource considerations applying theories on transaction-cost economics (Williamson, 1975; Ellram et al., 2008) or the resource-based view (Penrose, 1959; Jensen, 2012; Kedia \& Lahiri, 2011) respectively.

Moreover, there are inherent challenges with the concept of value and the study of value creation. This research attempted to untangle these issues and capitalized thereby on a multiple case study approach to outline value creation. However, the concept of value is subjective and perceived differently by individuals particularly with regards to indirect value creation. Indirect value creation is often overlooked or hidden and thus unrecognized as it is unanticipated. However, despite these challenges this research provides valuable information on the value creation in service offshoring. 


\section{REFERENCES}

Aarikka-Stenroos, L., \& Jaakkola, E. (2012). "Value co-creation in knowledge intensive business services: A dyadic perspective on the joint problem solving process". Industrial Marketing Management, 41(1), 15-26.

Anderson, J. C., \& Narus, J. A. (1998). "Business marketing: understand what customers value". Harvard Business Review, 76, 53-67.

Anderson, J. C., \& Narus, J. A. (1999). Business market management: understanding, creating and delivering value. Upper Saddle River: Prentice Hall.

Apte, U. M., \& Mason, R. O. (1995). "Global disaggregation of information-intensive services”. Management Science, 41(7), 1250-1262.

Armistead, C. G., \& Clark, G. (1993). "Resource Activity Mapping: The Value Chain in Service Operations Strategy”. Service Industries Journal, 13(4): 221-239.

Awate, S., Larsen, M. M., \& Mudambi, R. (2012). 'EMNE catch- up strategies in the wind turbine industry: Is there a trade- off between output and innovation capabilities?" Global Strategy Journal, 2(3), 205-223.

Bals, L., Daum, A. \& Tate, W. (2015) "From Offshoring to Rightshoring: Focus on the Backshoring Phenomenon". AIB Insights, 15(4): 3-8.

Bals, L., Jensen, P.D.O., Larsen, M.M., \& Pedersen, T. (2013). “Exploring layers of complexity in offshoring research and practice”. In T. Pedersen, L. Bals, P.D. Orberg Jensen, \& M. Moller Larsen (Eds.) The offshoring challenge: Strategic design and innovation for tomorrow's organization: 1-18. London: Springer.

Bertrand, O. \& Mol, M.J. (2013). "The antecedence and innovation effect of domestic and offshore R\&D outsourcing: The contingent impact of cognitive distance and absorptive capacity". Strategic Management Journal. 34(6), 751-760. 
Bettencourt, L., Ostrom, A., Brown, S., \& Roundtree, R. (2002). “Client Co-production in Knowledge-intensive Business Services. Operations management: a strategic approach", California Management Review, 44: 100-128.

Bhagat, R. S., Kedia, B. L., Harveston, P. D., \& Triandis, H. C. (2002). “Cultural variations in the cross-border transfer of organizational knowledge: An integrative framework". Academy of Management Review, 27(2), 204-221.

Brandl, K., Mudambi, R., \& Scalera, V. G. (2015). The Spectacular Rise of the Indian Pharmaceutical Industry. Entrepreneur \& Innovation Exchange.

Cohen, W. M., \& Levinthal, D. A. (1990). “Absorptive capacity: a new perspective on learning and innovation”. Administrative Science Quarterly, 128-152.

Cohen, W. M., \& Levinthal, D. A. (1990). “Absorptive capacity: A new perspective on learning and innovation”. Administrative Science Quarterly, 128-152.

Eisenhardt, K. M. (1989). "Building theories from case study research". Academy of Management Review, 14(4), 532-550.

Ellram, L. M., Tate, W. L., \& Billington, C. (2008). “Offshore outsourcing of professional services: A transaction cost economics perspective". Journal of Operations Management, 26(2), 148-163.

Flint, D. J., Woodruff, R. B., \& Gardial, S. F. (1997). "Customer value change in industrial marketing relationships: A call for new strategies and research". Industrial Marketing Management, 26(2): 163-175.

Floyd, S. W., \& Wooldridge, B. (1992). "Middle Management Involvement in Strategy and Its Association with Strategic Type: A Research Note”. Strategic Management Journal, 13: 153167. 
Foerstl, K., Kirchoff, J.F., \& Bals, L. (2016). "Reshoring and Insourcing: Drivers and Future Research Directions". International Journal of Physical Distribution and Logistics Management, 46 (5). Forthcoming.

Gooris, J., \& Peeters, C. (2014). "Home-host country distance in offshore governance choices”. Journal Of International Management, 20(1), 73-86.

Hartmann, E., Trautmann, G., \& Jahns, C. (2008). “Organisational design implications of global sourcing: A multiple case study analysis on the application of control mechanisms". Journal of Purchasing and Supply Management, 14(1), 28-42.

Jensen, P.D.O. (2012). “A passage to India: A dual case study of activities, processes and resources in offshore outsourcing of advanced services". Journal of World Business, 47(2): 311-326.

Kale, P., Dyer, J. H., \& Singh, H. (2002). “Alliance capability, stock market response, and long-term alliance success: the role of the alliance function”. Strategic Management Journal, 23(8): 747-767.

Kedia, B. L., \& Lahiri, S. (2007). “International outsourcing of services: A partnership model”. Journal of International Management, 13(1): 22-37.

Kedia, B. L., \& Mukherjee, D. (2009). “Understanding offshoring: A research framework based on disintegration, location and externalization advantages". Journal of World Business, 44(3): 250-261.

Ketokivi, M., \& Choi, T. (2014). "Renaissance of case research as a scientific method”. Journal of Operations Management, 32(5), 232-240.

Langley, A. (1999). "Strategies for theorizing from process data". Academy Of Management Review, 24(4), 691-710. 
Langley, A. (2007). "Process thinking in strategic organization". Strategic Organization, 5(3): $271-282$

Lewin, A. Y., \& Peeters, C. (2006). "Offshoring work: Business hype or the onset of fundamental transformation?” Long Range Planning, 39(3): 221-239.

Li, Y., Liu, Y., Li, M., \& Wu, H. (2008). “Transformational offshore outsourcing: Empirical evidence from alliances in China”. Journal of Operations Management, 26(2): 257-274.

Løwendahl, B. R. (1997). Strategic management of professional service firms. Copenhagen: Handelshøjskolens Forlag.

Løwendahl, B. R., Revang, Ø., \& Fosstenløkken, S. M. (2001). “Knowledge and value creation in professional service firms: A framework for analysis". Human Relations, 54(7): 911.

Macdonald, E. K., Wilson, H., Martinez, V., \& Toossi, A. (2011). “Assessing value-in-use: A conceptual framework and exploratory study". Industrial Marketing Management, 40(5), 671682.

Maister, D. (1993). Managing the Professional Service Firm. New York: The Free Press.

Manning, S., Massini, S., \& Lewin, A. Y. (2008). “A Dynamic Perspective on Next-Generation Offshoring: The Global Sourcing of Science and Engineering Talent". Academy of Management Perspectives, 22(3): 35-54.

Maskell, P., Pedersen, T., Petersen, B., \& Dick-Nielsen, J. (2007). “Learning Paths to Offshore Outsourcing: From Cost Reduction to Knowledge Seeking”. Industry and Innovation, 14(3): 239-257.

Mills, P. K., Chase, R. B., \& Margulies, N. (1983). "Motivating the client/employee system as a service production strategy". Academy of Management Review, 8(2), 301-310.

Murray, J. Y., \& Kotabe, M. (1999). "Sourcing strategies of US service companies: A modified transaction-cost analysis”. Strategic Management Journal, 20(9), 791-809. 
Normann, R. (2001). Reframing Business: When the map changes the landscape. Chichester: John Willey \& Sons Ltd.

Normann, R., \& Ramirez, R. (1994). Designing Interactive Strategy - From Value Chain to Value Constellation. Chichester: John Wiley \& Sons Ltd.

Nooteboom, B. (2009). A cognitive theory of the firm: Learning, governance and dynamic capabilities. Edward Elgar Publishing.

O'Farrell, P. N., \& Moffat, L. A. (1991). “An interaction model of business service production and consumption”. British Journal of Management, 2(4), 205-221.

Parasuraman, A., Zeithaml, V. A., \& Berry, L. L. (1985). “A conceptual model of service quality and its implications for future research". The Journal of Marketing, 41-50.

Payne, A. F., Storbacka, K., \& Frow, P. (2008). "Managing the co-creation of value”. Journal of the Academy of Marketing Science, 36(1), 83-96.

Peeters, C., Dehon, C., \& Garcia-Prieto, P. (2014). “The attention stimulus of cultural differences in global services sourcing”. Journal of International Business Studies, 46(2), 241251.

Peeters, C., Lewin, A., Manning, S., \& Massini, S. (2010). Shifting Firm Boundaries in Global Service Sourcing: Transaction Costs, Emerging Capabilities and Experiences-based Learning, Opening Up Innovation: Strategy, Organization and Technology. Imperial College London Business School.

Penrose, E. T. (1959). The theory of the growth of the firm. New York: John Wiley \& Sons.

Prahalad, C. K., \& Ramaswamy, V. (2000). “Co-opting customer competence”. Harvard Business Review, 78(1), 79-90.

Prahalad, C. K., \& Ramaswamy, V. (2004). "Co-creation experiences: The next practice in value creation". Journal Of Interactive Marketing, 18(3), 5-14. 
Ravald, A., \& Grönroos, C. (1996). “The value concepts and relationship marketing European”. Journal of Marketing, 30(2): 13.

Simonin, B. L. (2004). “An empirical investigation of the process of knowledge transfer in international strategic alliances”. Journal of International Business Studies, 407-427.

Stabell, C. B., \& Fjeldstad, Ø. D. (1998). “Configuring Value for Competitive Advantage: On Chains, Shops, and Networks". Strategic Management Journal, 19(5): 413-437.

Stuart, I., McCutcheon, D., Handfield, R., McLachlin, R., \& Samson, D. (2002). "Effective case research in operations management: a process perspective". Journal of Operations Management. 20(5), 419-433.

Sutton, R. I., \& Staw, B. M. (1995). "What Theory is Not". Administrative Science Quarterly, 40(3): 371-384.

Tate, W. L., Ellram, L. M., Bals, L., \& Hartmann, E. (2009). “Offshore outsourcing of services: An evolutionary perspective”. International Journal of Production Economics, 120(2), 512524.

Teece, D. J. (1984). "Economic analysis and strategic management". California Management Review, 26(3): 87-110.

Thompson, J. D. (1967). Organizations in Action: Social Science Bases of Administrative Theory. New York: McGraw-Hill.

UNCTAD. (2004). United Nations Commission on Trade and Development/World Investment Report - The Shift Towards Services. Geneva: United Nations Commission on Trade and Development.

Van de Ven, A. H. (1992). "Suggestions for Studying Strategy Process: A Research Note”. Strategic Management Journal, 13: 169-191. 
Vargo, S. L., \& Lusch, R. F. (2004). "Evolving to a new dominant logic for marketing”. Journal of Marketing, 68(1), 1-17.

Vargo, S. L., Maglio, P. P., \& Akaka, M. A. (2008). “On value and value co-creation: A service systems and service logic perspective”. European Management Journal, 26(3), 145-152.

Von Nordenflycht, A. (2010). "What is a professional service firm? Toward a theory and taxonomy of knowledge-intensive firms". Academy of Management Review, 35(1), 155-174.

Voss, C., Tsikriktsis, N., \& Frohlich, M. (2002). "Case research in operations management”. International Journal Of Operations \& Production Management, 22(2), 195-219.

Walter, A., Ritter, T., \& Gemünden, H. G. (2001). "Value creation in buyer-seller relationships: Theoretical considerations and empirical results from a supplier's perspective". Industrial Marketing Management, 30(4), 365-377.

Weerakkody, V., \& Irani, Z. (2010). “A value and risk analysis of offshore outsourcing business models: an exploratory study”. International Journal of Production Research, 48(2): 613-634.

Williamson, O. E. (1975) Markets and hierarchies: Analysis and antitrust implications. New York: Free Press.

Woodruff, R. B. (1997). "Customer value: the next source for competitive advantage”. Journal of the Academy of Marketing Science, 25(2), 139-153

Wooldridge, B., Schmid, T., \& Floyd, S. W. (2008). “The Middle Management Perspective on Strategy Process: Contributions, Synthesis, and Future Research”. Journal of Management, 34(6): 1190-1221.

Yin, R. (2003). Case study research: Design and methods. $3^{\text {rd }}$ edition. Sage Publications: Thousand Oaks. 
Youngdahl, W., Ramaswamy, K., \& Verma, R. (2008). "Exploring new research frontiers in offshoring knowledge and service processes". Journal of Operations Management, 26(2): 135140. 
Figure 1: Direct and indirect value creation in offshored knowledge intensive services

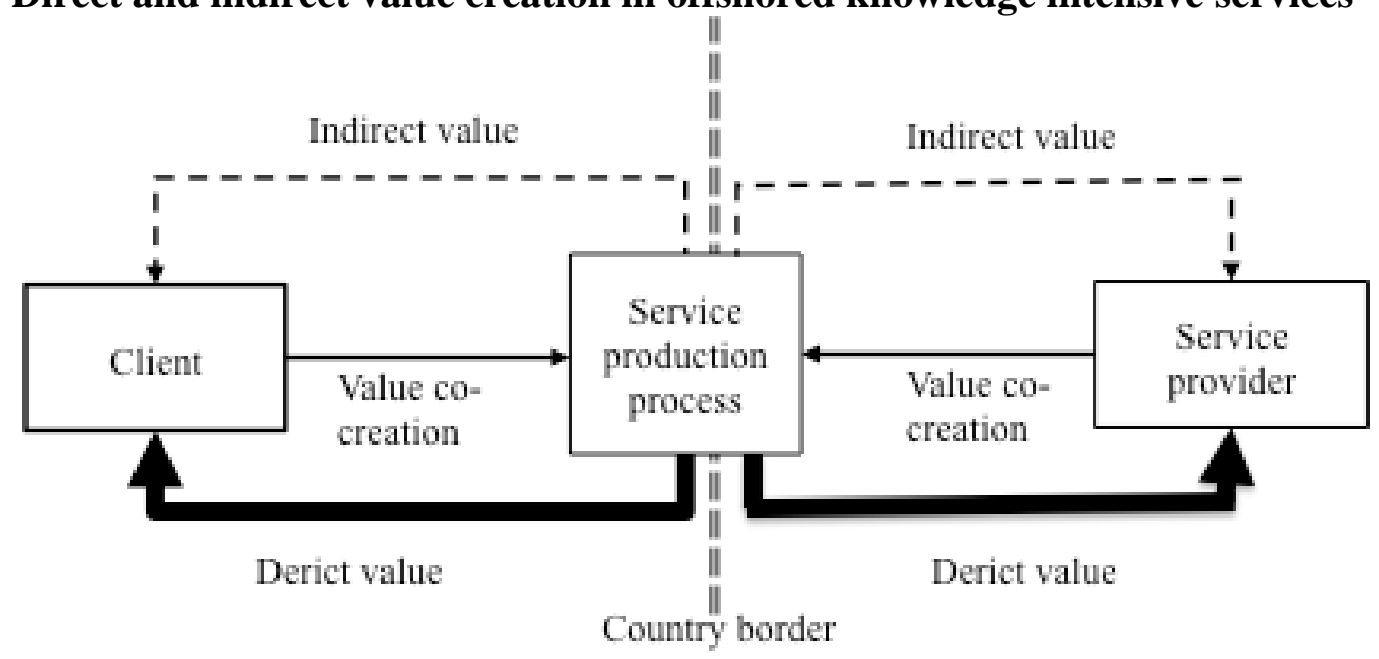


Table 1: Case descriptions

\begin{tabular}{|c|c|c|c|}
\hline Case & $\mathbf{A}$ & B & $\mathbf{C}$ \\
\hline Service & $\begin{array}{l}\text { Market } \\
\text { Intelligence }\end{array}$ & $\begin{array}{l}\text { Project } \\
\text { Management } \\
\text { Support }\end{array}$ & $\begin{array}{l}\text { Financial } \\
\text { Management } \\
\text { Reporting \& } \\
\text { Reconciliation }\end{array}$ \\
\hline $\begin{array}{l}\text { Description of } \\
\text { service tasks }\end{array}$ & $\begin{array}{l}\text { Report writing } \\
\text { and design } \\
\text { update of } \\
\text { standard } \\
\text { financial or } \\
\text { operation } \\
\text { models }\end{array}$ & $\begin{array}{l}\text { Research and } \\
\text { project support }\end{array}$ & $\begin{array}{l}\text { Collection and } \\
\text { analysis of } \\
\text { financial data }\end{array}$ \\
\hline $\begin{array}{l}\text { Service team in } \\
\text { service provider }\end{array}$ & SPA & SPB & SPC \\
\hline $\begin{array}{l}\text { Business unit of } \\
\text { client }\end{array}$ & $\mathrm{CA}$ & $\mathrm{CB}$ & $\mathrm{CC}$ \\
\hline $\begin{array}{l}\text { Client division } \\
\text { (location) }\end{array}$ & $\begin{array}{l}\text { Strategic } \\
\text { Operations } \\
\text { (Netherlands, } \\
\text { all global } \\
\text { terminals) }\end{array}$ & $\begin{array}{l}\text { Project } \\
\text { Management } \\
\text { (Netherlands) }\end{array}$ & $\begin{array}{l}\text { Financial } \\
\text { Operations } \\
\text { (Denmark, } \\
\text { Sweden, } \\
\text { Singapore) }\end{array}$ \\
\hline Offshored since & 2010 & 2010 & 2010 \\
\hline $\begin{array}{l}\text { Interviews } \\
\text { (client/provider) }\end{array}$ & $6 / 11$ & $7 / 11$ & $5 / 11$ \\
\hline
\end{tabular}


Table 2: Validity and reliability of research

\begin{tabular}{l|l} 
Type of validity & $\begin{array}{l}\text { Methods of addressing validity and reliability in case } \\
\text { studies }\end{array}$ \\
\hline $\begin{array}{l}\text { Construct validity } \\
\text { (correct external } \\
\text { measures for concepts } \\
\text { under study) }\end{array}$ & $\begin{array}{l}\text { Triangulation of interview partners from the service provider } \\
\text { and the client firms } \\
\text { Triangulation of interview data with secondary data (e.g. } \\
\text { Standard operating procedures and firm internal documents) } \\
\text { Recording of all data and transcription } \\
\text { After-interview note transcriptions } \\
\text { Follow up interviews till saturation was reached } \\
\text { Use of the value shop framework to outline production process }\end{array}$ \\
\hline $\begin{array}{l}\text { Internal validity } \\
\text { (appropriate } \\
\text { interpretation of data) }\end{array}$ & $\begin{array}{l}\text { Use of the value shop framework to identify were clients co- } \\
\text { created value } \\
\text { Identification of direct and indirect value according to } \\
\text { responses by the service provider and client. Direct value } \\
\text { (contract related and pre-service production established based } \\
\text { on expectations), indirect value out of activities done and } \\
\text { actions taken within the production process. }\end{array}$ \\
\hline $\begin{array}{l}\text { External validity } \\
\text { (enhanced } \\
\text { generalizability) }\end{array}$ & $\begin{array}{l}\text { Sampling is reflecting a variety of services types of knowledge- } \\
\text { intensive services and all cases are produced according to the } \\
\text { conceptual model. The framework is applicable to different } \\
\text { services and their value creation. }\end{array}$ \\
\hline $\begin{array}{l}\text { Reliability } \\
\text { (possible repetition of } \\
\text { findings) }\end{array}$ & $\begin{array}{l}\text { Reliability is reached as parts of the model were used to study } \\
\text { service production processes before. Moreover, the } \\
\text { questionnaire allows for repetition and showing also } \\
\text { transparency. }\end{array}$ \\
\hline
\end{tabular}

Note: Types of validity based on Yin (2003) 
Table 3: Production processes

\begin{tabular}{|c|c|c|c|c|c|c|}
\hline Case & & $\begin{array}{l}\text { Problem-finding } \\
\text { \& acquisition }\end{array}$ & Problem solving & Choice & Execution & $\begin{array}{l}\text { Monitoring \& } \\
\text { Evaluation }\end{array}$ \\
\hline $\begin{array}{l}\text { B } \\
\text { Project } \\
\text { Management } \\
\text { Support }\end{array}$ & $\begin{array}{l}\text { Service } \\
\text { provider } \\
(\mathrm{SPB})\end{array}$ & $\begin{array}{l}\text { Identifies need for } \\
\text { project support } \\
\text { such as terminal } \\
\text { enlargement } \\
\text { Tries to understand } \\
\text { project and the } \\
\text { required work }\end{array}$ & $\begin{array}{l}\text { Suggests improvements } \\
\text { or amendments to } \\
\text { suggested way to support } \\
\text { project }\end{array}$ & $\begin{array}{l}\text { Summarizes and } \\
\text { communicates } \\
\text { project support } \\
\text { approach }\end{array}$ & $\begin{array}{l}\text { Helps during execution if } \\
\text { needed. } \\
\text { Receives project support. } \\
\text { Reimburses SPB during and } \\
\text { at end of project. } \\
\text { Helps during project with } \\
\text { information and project } \\
\text { support }\end{array}$ & $\begin{array}{l}\text { Evaluation and } \\
\text { feedback request } \\
\text { to improve } \\
\text { service }\end{array}$ \\
\hline $\begin{array}{l}\text { C } \\
\text { Financial } \\
\text { Management } \\
\text { Reporting \& } \\
\text { Reconciliation }\end{array}$ & $\begin{array}{l}\text { Service } \\
\text { provider } \\
(\mathrm{SPC})\end{array}$ & $\begin{array}{l}\text { Identifies need for } \\
\text { financial } \\
\text { information and } \\
\text { reconciliation } \\
\text { Acknowledges } \\
\text { need for } \\
\text { information and } \\
\text { reconciliation }\end{array}$ & $\begin{array}{l}\text { Makes suggestions how } \\
\text { information can be found } \\
\text { and used } \\
\text { Identifies where and } \\
\text { what information is } \\
\text { needed or where } \\
\text { reconciliation is needed }\end{array}$ & $\begin{array}{l}\text { Informs about } \\
\text { start of } \\
\text { execution }\end{array}$ & $\begin{array}{l}\text { Generates information and } \\
\text { executes service delivery to } \\
\text { CC }\end{array}$ & $\begin{array}{l}\text { Occasionally } \\
\text { sends evaluation } \\
\text { forms }\end{array}$ \\
\hline
\end{tabular}


Table 4: Direct and indirect value creation in the offshored service production process

\begin{tabular}{|c|c|c|c|c|}
\hline \multirow[b]{2}{*}{ Creation of: } & \multicolumn{2}{|r|}{ Client } & \multicolumn{2}{|r|}{ Service provider } \\
\hline & Direct value via & Indirect value via & Direct value via & Indirect value via \\
\hline $\begin{array}{l}\text { Problem- } \\
\text { finding \& } \\
\text { acquisition }\end{array}$ & & $\begin{array}{l}\text { - enhanced understanding of } \\
\text { problems }\end{array}$ & & - knowledge about the client \\
\hline $\begin{array}{l}\text { Problem- } \\
\text { solving }\end{array}$ & & $\begin{array}{l}\text { - enhanced understanding of } \\
\text { operations }\end{array}$ & & - problem-solving knowledge \\
\hline Choice & & & & \\
\hline Execution & $\begin{array}{l}\text { - service delivery } \\
\text { - cheap service fares }\end{array}$ & $\begin{array}{l}\text { - enhanced international } \\
\text { communication } \\
\text { - enhanced international team } \\
\text { coordination }\end{array}$ & $\begin{array}{l}\text { - financial } \\
\text { reimbursement }\end{array}$ & $\begin{array}{l}\text { - enhanced international communication } \\
\text { - enhanced international team } \\
\text { coordination }\end{array}$ \\
\hline $\begin{array}{l}\text { Monitoring \& } \\
\text { evaluation }\end{array}$ & & & & - perceived service quality knowledge \\
\hline
\end{tabular}

